\title{
Attitude VS Involvement - A systematic literature review at the intersection between Engagement and Innovation
}

\author{
Daniel Trabucchi \\ School of Management - Politecnico di Milano \\ daniel.trabucchi@polimi.it \\ Paola Bellis \\ School of Management - Politecnico di Milano \\ paola.bellis@polimi.it \\ Diletta Di Marco \\ School of Management - Politecnico di Milano \\ diletta.dimarco@polimi.it \\ Tommaso Buganza \\ School of Management - Politecnico di Milano \\ tommaso.buganza@polimi.it \\ Roberto Verganti \\ Stockholm School of Economics \\ roberto.verganti@hhs.se
}

\section{Acknowledgements}

The authors would like to acknowledge Federico Testa, who provided a valuable contribution in early stages of this research.

This is the post-print version of the paper published on the European Journal of Innovation Management please cite as

Trabucchi, D., Bellis, P., Di Marco, D., Buganza, T. and Verganti, R. (2020), "Attitude vs involvement: a systematic literature review at the intersection between engagement and innovation", European Journal of Innovation Management, Vol. ahead-of-print No. ahead-ofprint. https://doi.org/10.1108/EJIM-05-2020-0171 


\begin{abstract}
Purpose: In a world where innovation became a "buzzword," and everyone within companies is required to foster innovation, the engagement of people towards innovation is fundamental to prompt individual motivation and actions to make innovation happen. However, despite the relevance of the relationship between engagement and innovation, the literature on the topic appears still fragmented. The purpose of this study is to provide an overview of the topic through a systematic literature review.

Design/Methodology/Approach: A final sample of 108 papers has been selected and analyzed through co-citation and text mining analyses. The former enabled the analysis of the structure of the theoretical foundation of the filed, while the latter facilitates a systematic and unbiased contentdriven review of the literature.

Findings: The results of the analysis suggest two main areas of interest describing the relationship between engagement and innovation. On the one hand, there is the focus on "engagement as an attitude", intended as the capacity of individuals to generate and realize innovation. On the other, there is a stream of literature focused on "engagement as involvement, " which refers to coinnovation paradigms, involving both internal and external stakeholders.

Research limitations/Implications: From an academic perspective, this paper highlights the relevance of the "human-side" of innovation, proposing avenues for future research that dig into the relationship between people's engagement and innovation dynamics. Moreover, it shows how the recent developments in the innovation management literature are coherent with this emerging relevance of the human perspective in innovation.

Practical Implications: From a practitioner perspective, this paper helps managers by highlighting the two different approaches that they can have in terms of engagement. The study aims to help them in identifying the kind of engagement they are looking for in their employees and other innovation stakeholder having the support to find relevant studies in that direction.

Originality: The study unveils how the evolution of both areas over the years is strictly related to the megatrends of innovation fields, which are the main areas of knowledge not covered yet. Therefore, a research agenda is proposed.
\end{abstract}

Keywords: Innovation; Engagement; Systematic Literature Review; Employees; Involvement; Attitude; Text Mining; Co-Citation 


\section{Introduction}

In a fast-changing world, overcrowded by ideas and opportunities, one of the biggest challenges for companies is not to generate ideas but to engage people towards innovation (Verganti, 2017). Organizations operate and compete in a complex and turbulent environment because of major forces such as digital transformations and cross-industry global trends like big data and social media (Matzler et al., 2018; Lee et al., 2012). All these factors provide an incredible amount of possibilities for innovation in terms of new products, the value chain, and the business models (Smedley 2017). In understanding how to deal with this environment, a lot has been said about the process of innovation and the strategies to improve the quantity and the quality of innovation initiatives (Brenton \& Levin, 2012). Innovation scholars focused mainly on the process to foster innovation, considered as a defined sequence of decision points (Cooper, 1990; Krishnan and Ulrich 2001). Therefore, much attention has been put on how to execute such processes in a fast and iterative way to navigate the complexity of a highly dynamic market environment. However, these approaches define innovation development as a deliberate business process which involves scores of generic decisions (Krishnan and Ulrich, 2001), and metrics to assess performances (Slater et al., 2014). They neglect entirely the role of people as members of a social system (Rogers, 1962), who can bring in the process not only their capabilities and skills (Shane and Ulrich, 2004), but also their ideas, values, and perspective (Brenton \& Levin, 2012).

Nevertheless, innovation is not just generating ideas and pooling technical skills within a crossfunctional team. It also requires moments of playfulness (Mainemelis \& Ronson, 2006), time, immersion, and reflection (Brenton \& Levin, 2012). Simultaneously, innovation is also about volunteerism, energy, and motivation (O'Connor \& Mc Dermott, 2004). Hence, in the current environment, a deeper understanding of how people engage, make sense, and collaborate in innovation appears fundamental (e.g., Alblooshi et al., 2020; Bellis \& Verganti, 2020).

In particular, people's engagement appears as crucial to spur an individual's motivation and action in making innovation happen. In a way, engagement seems to reflect a positive psychological state of motivation with behavioral manifestation, both cognitive and emotional, resulting in the active involvement of a person (Shuck \& Wollard, 2010). Still, what is the current state of research at the intersection between engagement and innovation? The present study aims to explore such a research question.

The interest in "engagement" as a research topic is dated back at the end of the last century (Kahn, 1990). Nevertheless, today as never before, the understanding of what moves an employee to provide their contribution to business processes has become relevant, and it is even more appropriate for what concerns innovation. The purpose of the present study is to provide a systemic overview of what has been said in the field and provide a critical analysis that may help innovation scholars and innovation managers in highlighting relevant spots for future research. More precisely, the paper explores how the literature sheds light on the relationship between Engagement and Innovation through a systematic literature review. Whereas, in academic literature, the engagement-innovation relationship appears still fragmented and does not provide a single study comprehensively analyzing the topic (Janssen, 2003; Shuck and Wollard, 2010). Thus, the paper aims to understand how scholars conceptualized and studied Engagement in Innovation activities.

The study's results suggest how people engagement may be different according to the specific objective of the innovation activities. Through this work, we identify two kinds of engagement: engagement as involvement and engagement as an attitude. The former identifies engagement as a form of active collaboration towards the innovation initiative. While the latter identifies engagement as a mindset people need to adopt and develop in order to embrace innovation challenges. 
Leveraging on these findings, the study aims to contribute both to theory and practice. Form a theoretical perspective, the study aims to clarify the engagement-innovation relationship, providing insights about how the two kinds of engagement differ and how they can support innovation activities. Besides, building on the findings proposed, the study presents a research agenda for further exploration in the field.

From a managerial perspective, the study support managers by suggesting how people engagement may differ according to the specific innovation purposes. More precisely, according to our findings, engagement might have different nuances: from only involving people to collaborate on the one side, until nurturing their mindset and attitude towards making innovation happen.

Finally, the paper is structured as follow. First, an overview about Engagement literature is provided, it is crucial to understand the topic's state of the art before to relate it to the one of Innovation. Then, we introduce the methodology followed to perform the systematic literature review. Subsequently, the results are presented as well as both kinds of engagement (involvement and attitude) are introduced. Finally, a discussion of the main findings is provided before to conclude with a research agenda for further development in the field.

\section{Theoretical Background}

The engagement concept dates back to the 1990s when it started to attract academic interest. During its development, the idea of engagement has been attached to several different definitions ranging from "personal engagement," to "job engagement" till "employee engagement" when it refers explicitly to organizational contexts (Kahn, 1990; Schaufeli and Bakker, 2004; Robinson, 2004; Alfes et al., 2010).

The seminal definition is attributable to Kahn (1990) who defines the concept as "people exhibit engagement when they become physically involved in tasks, whether alone or with others; they are cognitively vigilant focused, and attentive; they are emotionally connected to their work and others in the service of their work." Referring to Welch's (2011) engagement review, the evolution of engagement can be contextualized in three different periods, or "waves."

The first wave has been mainly characterized by Kahn mentioned above (1990), The third wave is defined by Welch (2011) that linked engagement with other disciplines' contributions coming from human resources, workplace behavior, and psychology (Welch, 2011).

The first wave has been mainly characterized by Kahn (1990) imprinting, with a shared focus on engagement as physical - vigor, emotional - dedication, and cognitive - absorption (Schaufeli and Bakker, 2004). While "vigor" implies "high energy levels and mental resilience when working," "dedication" refers to "being strongly involved in one's work and experiencing a sense of significance, enthusiasm, and challenge"; finally, "absorption" means "to be fully concentrated and engrossed in one's work" (Schaufeli and Bakker, 2004). This first wave represents the seminal work on engagement, highly oriented to the organizational context, and the relationship between people and their job.

The second wave is evident in the first half of the 2000s when another influential definition was coined from Schaufeli and Bakker (2004). They consider engagement in the organizational behavior context defining it as: "a positive, fulfilling, work-related state of mind that is characterized by vigor, dedication, and absorption." Robinson (2004) also contributed to the second publication wave defining the concept of engagement as "a positive employee attitude towards the organization and its values, involving awareness of business context, and work to improve job and organizational effectiveness." It is evident how, consistently with the first wave, this second group is characterized by the term "positive," which defined the turning point respect to the focus from negative 
consequences of work attitudes popular in that time (i.e., job burnout). Such a switch triggered the advent of academic works on engagement starting from this period: one the most popular is Saks (2006), who defined organizational support and job characteristics as job engagement antecedents. This second wave highlights the role of a positive dimension in the organization and, more broadly, the business context.

Welch (2011) initiated the third and last publication wave. It began with further scientific interest intensification near the end of the decade when the engagement concept started to be linked to other disciplines' contributions from human resources, workplace behavior, and psychology (Welch, 2011). The primary engagement conceptualization production ends with this third wave, leaving the academia with a plethora of not exhaustive definitions and a widely accepted taxonomy (Schaufeli et al., 2002).

Multiple academic conceptualizations are underlining its multifaceted nature due to the presence of constructs intersecting social and psychological sciences (Robinson, 2004; Alfes et al., 2010), highlighting this difficulty in finding a reliable and well-comprehensive definition and a subsequent valid measurement system. The concept of engagement is an integration of behavioral, emotional and cognitive components, encompassing ideas such as energy, rational and emotive attachment, deep connection, positive attitude, and psychological presence (Rich et al., 2010).

Recently, organizations began to adopt a more open approach to engagement by considering it as a substantial psychological adaptation and involvement from the part of employees to the organization (Schaufeli and Bakker, 2004). This shift can be attributed to how the engagement notion has quickly evolved within the practitioner community, hampering the understanding of work engagement for practical purposes (Anitha, 2014). The concept of engagement, given the advent of the fourth industrial revolution (Klaus, 2016), has passed from the definition of mere physical exploitation of the employees to a desirable active espousal of the entire "person" to the work sphere in modern organizations.

Thus, nowadays, engagement can be considered an essential condition for employees and the organization they work for (Saks, 2006). Indeed, researchers interpret engagement as a property of organizations; that is, employees throughout the organization may share perceptions that members of the organization collectively invest their full selves into their work roles (Dvir et al., 2002). For example, motivational states such as engagement are highly transferrable to other members of the organization (Murray, 2015). Given the fact that organizational engagement involves psychological processes occurring within individuals, as they attribute meaning to the environment in which they work and transform it. At the same time, they disseminate it; for this paper, we consider engagement at the individual level (Seibert, Silver, \& Randolph, 2004).

Thus, employee engagement means that organizations are now endowing their efforts at mobilizing the motivation of their human capital, even creating a potential source of innovation to contribute and help drive the organization forward (Bessant, 2003). It has been indeed defined also as a positive capability to foster mind-openness and out-of-the-box thinking making individuals more willing to achieve meaningful innovations, for themselves and ultimately for the whole organization (Eldor, 2017; Jena and Memon, 2018; Jung and Yoon, 2018)

The benefits of highly engaged and innovative employees are clear from numerous innovation management studies (Chughtai, 2011; Janssen, 2000; Oldham and Cummings, 1996; Robinson and Schroeder, 2004; Teerikangas and Valikangas, 2012). It implies that academic interest has slightly started to concentrate not only on how to enable employees to be engaged in their work but also how to be too motivated in creating innovation (De Spiegelaere et al., 2014; Verona and Prandelli, 2002; Füller, 2006). 
Although the increasing current interest nested within the engagement-innovation relationship, academic literature evidence is still fragmented and does not provide a single study comprehensively analyzing the topic (Janssen, 2003; Shuck and Wollard, 2010). Thus, providing an exhaustive analysis of the relationship between engagement and innovation through a Bibliometric Systematic Literature Review is pivotal. In completing this research, our literature review's main driver is to aspire to give an innovative framework to answer how the literature has contributed to shedding light on the relationship between engagement and innovation.

\section{Research Design}

Systematic Literature Reviews are widely diffused in the innovation literature. They focus on both broad and specific topics using traditional (e.g., Lill et al., 2020) and bibliometric approaches (e.g., Suominen et al., 2019). This research relies on both approaches, also using co-citation and text mining techniques, as later explained.

\section{Sample Selection}

To reach the research aims, a structured approach to review the literature has been applied (Tranfield et al., 2003). To reach the final sample of focal articles, this study adopted a systematic approach (e.g., Randhawa et al. 2016; Magistretti et al., 2020), summarized in Figure 1, with a final sample of 108 articles published in leading business journals (indexed in Scopus). The research phase was conducted during 2019, therefore the literature search is updated to the end 2018.

The review process was conducted by searching the SciVerse Scopus online database for scientific articles. This Database was chosen for its' completeness since being less selective than other, potentially leads to a larger selection of international outlets is available which, in turn, convinced the authors to select it as the preferred choice for its fit with such a crosscutting topic as engagement in innovation (e.g., Ghezzi et al.,2018).

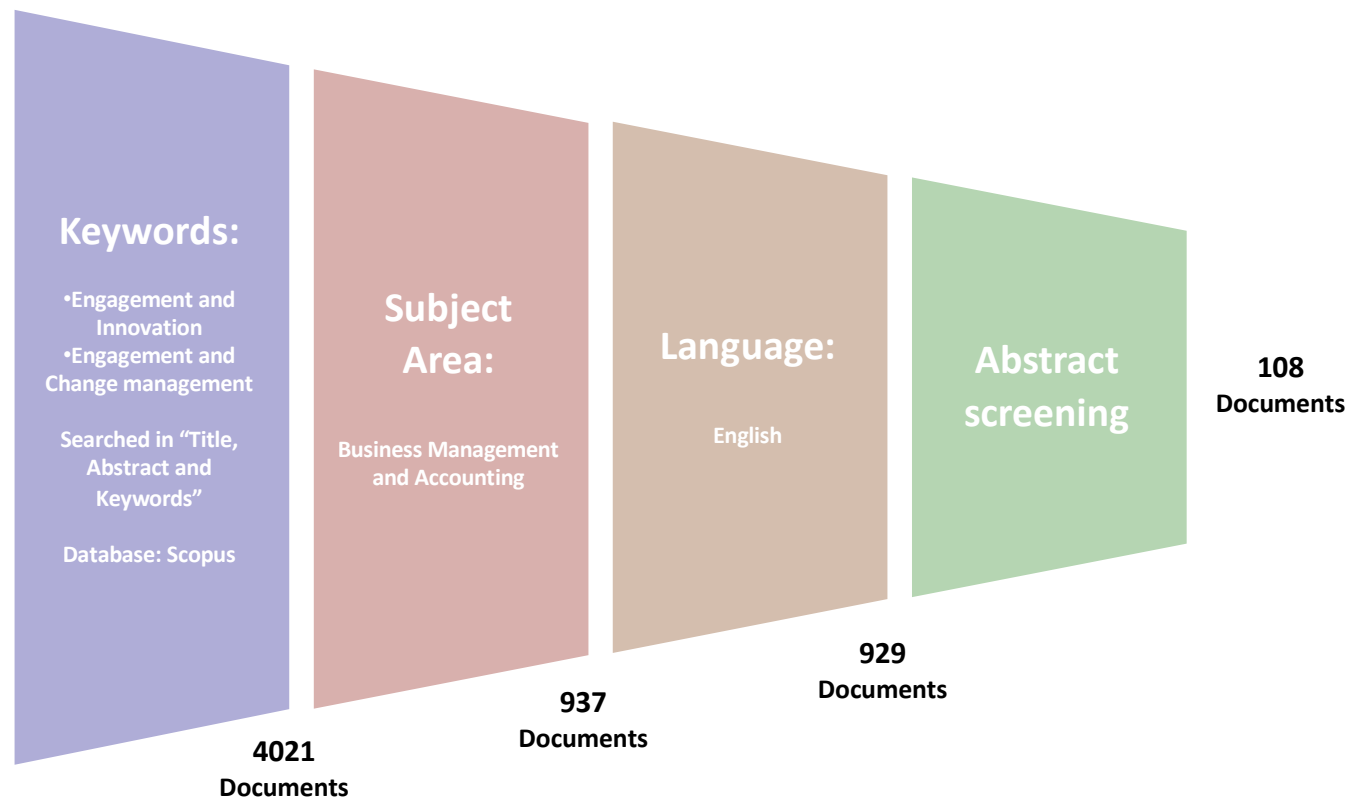

Figure 1 - Filtering process and definition of the final database 
The first step aimed to identify relevant concepts to the area of investigation (definition of the keywords for the literature search). As previously mentioned, our research aims to focus on the intersection between the concepts of "innovation" and "engagement," which are the first two keywords used for the search. When the object of the innovation process is the people, their behaviors, and how they act within an organization, the literature often refers to the term "change management" rather than "innovation". Therefore, to have a broader view of the topic, we also included the keywords "change management" and "engagement" as queries. The search of the two sets of keywords in the field of "Abstract, Title and Keywords" brought to 4021 initial results. The following steps limited the results to the area ("Business, Management, and Accounting") and the language (English), bringing to 929 documents A specific further filter for the time frame was included (1990-2018) considering the available papers published in succession to the seminal paper introducing the concept of engagement (Kahn,1990). For the final step of the screening process, the authors have independently reviewed all the abstracts, to identify the definitive sample.

Among the abstracts reviewed by the whole pool of authors, only 108 papers have been considered potentially aligned with the research objective of this study. Most important, as exclusion criteria, the authors considered that other papers used the word "engagement" with different meanings, such as a synonymous for commitment in an investment (Nemet, 2009) or not related to innovation activities (e.g., Van Looy et al., 2004). The papers resulting in the final sample have been read and analyzed qualitatively and through quantitative tools: co-citation analysis and text mining.

\section{Co-Citation Analysis}

References in a paper may show silent relationships (Gmür 2003; Small 1973). Co-citation is a technique that measures the frequency with which two items (articles, authors, sources) are cited together. It is becoming more and more popular in the management field, e.g., in innovation (e.g., Randhawa et al., 2016) or business ethics (e.g., Calabretta et al. 2011). The final goal is to provide an indicator of the affinity and proximity between the two items (White and Griffin 1981).

Therefore, co-citation was used to analyze the structure of the theoretical foundation of the filed. It was used at the paper level, explaining at the same time multiple contributions by a single author. At first, a network is drawn showing the links between the most co-cited papers. In order to increase the network readability of theselected sample of 108 papers, articles with less than six citations were excluded (e.g., Randhawa et al. 2016).

A smart local moving algorithm is then used to analyze the network (Waltman and Van Eck 2013) and to provide a cluster analysis of related publications (Waltman, Van Eck, and Noyons 2010). The software sets the number of clusters based on the resolution parameter. The parameter was added to avoid the failure of identifying small groups (Fortunato and Barthélemy 2007). Indeed, the algorithm is based on the modularity function, which is famous among network scientists (see Fortunato 2010). Nevertheless, it is affected by the resolution limit problem, which is here limited by the resolution parameter.

\section{Text Mining Analysis}

Text mining aims to find detailed conceptual insights through an unstructured ontological discovery using the words as the unit of analysis. It shows a systematic and unbiased content-driven review of the literature (e.g., Biesenthal and Wilden 2014; Randhawa et al. 2016). It is becoming more and more diffused in innovation research (Antos et al., 2020).

To accomplish the result of this last quantitative analysis, the textual data mining software Leximacer 4.0 was used (e.g., Randhawa et al. 2016). 
Previous research showed that these tools present a close agreement with expert judgment (Campbell et al. 2011; Rooney 2005). The analyses performed by the software aim to highlight the most frequently used concepts in a text and to define the relationships between them.

The software has been used to systematically reveal critical concepts in the field, through the identification of seed words (thematic analysis of the documents) that have been linked through the frequency and the co-occurrence within their contexts (semantic analysis) (Mathies and Burford 2011).

\section{Results}

\section{Descriptive Results}

Even if early investigation at the intersection between engagement and innovation occurred in the '90s (e.g., Khan, 1990; Smith, 1994), only in the early 2000s, the growth rate of studies about engagement in innovation increases significantly (Figure 2). In particular, Alfes and colleagues (2010) 
were the firsts investigating engagement within the field of innovation; their study seems to be the trigger of knowledge at the intersection of the two major domains.

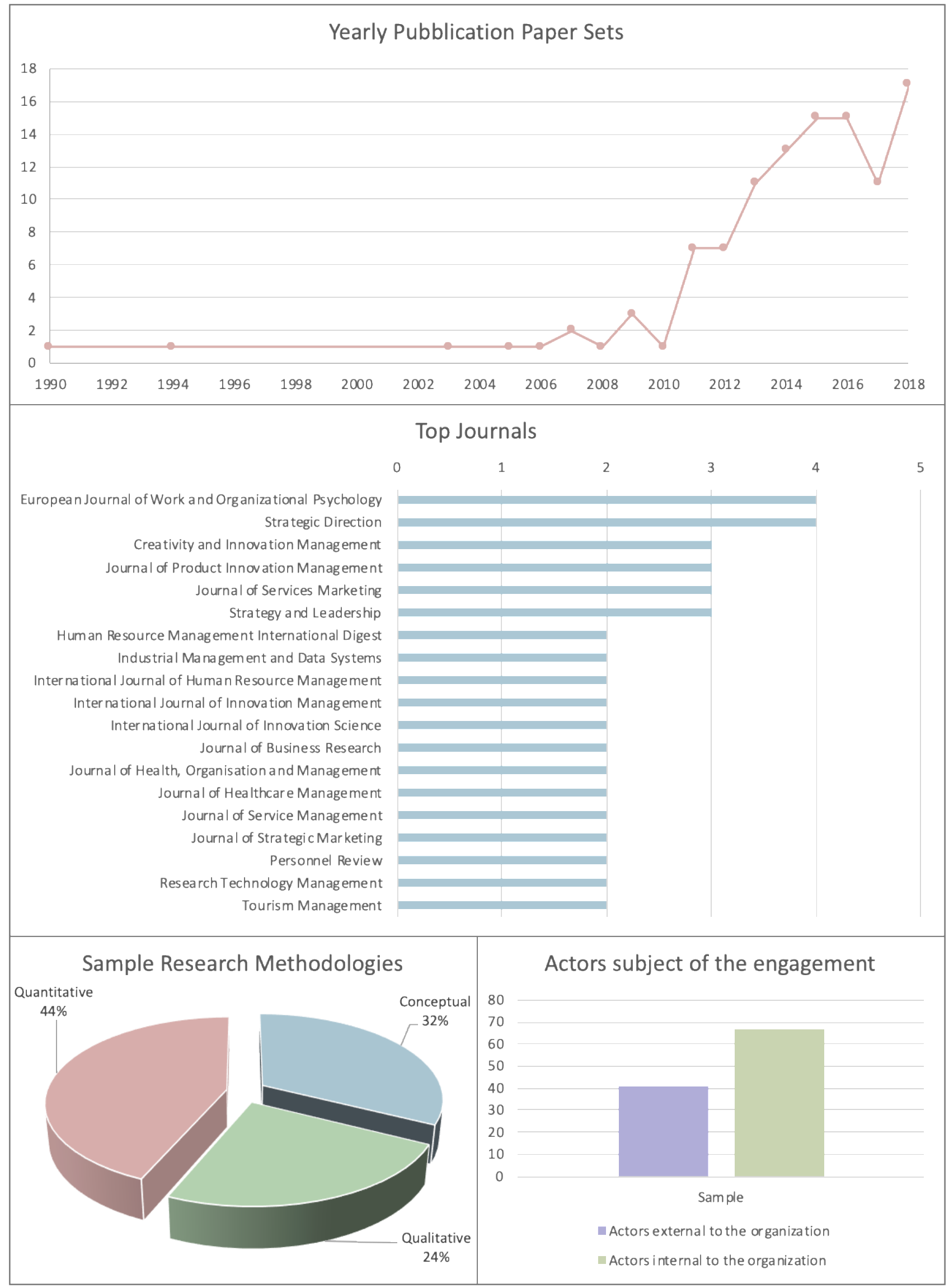

Figure 2 - Descriptive results of the Sample 
There is a wide variety of Journals that in the timespan abovementioned published studies around the fields of engagement and innovation. As represented in Figure 2, there are journals from various fields of knowledge such as psychology (European Journal of Work and Organizational Psychology), innovation management (Creativity and Innovation Management, Journal of Product Innovation Management, International Journal of Innovation Management) or HR management (Human Resource Management International Digest, International Journal of Human Resource Management), to others more specific context such as healthcare (Journal of Health, Organization and Management and Journal of Healthcare Management) and tourism (Tourism Management).

The field seems quite sparse: overall, 19 journals are present in the database, and the most popular in the area has only four papers. Something similar emerges from the analysis of the ten most cited articles in the sample (Table 1): they have been published across nine different journals, from very different fields such as Marketing (Journal of Interactive Marketing), Strategy and Management (Strategy and Leadership, California Management Review), and Human Resources (International Journal of Human Resource Management).

\begin{tabular}{|c|c|c|c|c|}
\hline Authors & Title & Year & Journal & $\begin{array}{l}\text { Cited } \\
\text { by }\end{array}$ \\
\hline $\begin{array}{l}\text { Sawhney M., } \\
\text { Verona G., Prandelli } \\
\text { E }\end{array}$ & $\begin{array}{l}\text { Collaborating to create: The internet Platform for } \\
\text { customer engagement in product innovation }\end{array}$ & 2005 & $\begin{array}{l}\text { Journal of interactive } \\
\text { Marketing }\end{array}$ & 571 \\
\hline $\begin{array}{l}\text { Lee S.M., Olson } \\
\text { D.L., Trimi S. }\end{array}$ & $\begin{array}{l}\text { Co-innovation: Convergenomics, collaboration, } \\
\text { and co-creation for organizational values }\end{array}$ & 2012 & Management Decision & 203 \\
\hline $\begin{array}{l}\text { Agarwal R., Selen } \\
\text { W. }\end{array}$ & $\begin{array}{l}\text { Dynamic capability building in service value } \\
\text { networks for achieving service innovation }\end{array}$ & 2009 & Decision Sciences & 148 \\
\hline Füller J. & $\begin{array}{l}\text { Why consumers engage in virtual product } \\
\text { development initiated by producers }\end{array}$ & 2006 & $\begin{array}{l}\text { Advances in Consumer } \\
\text { Research }\end{array}$ & 108 \\
\hline Ramaswamy V. & Leading the transformation to co-creation of value & 2009 & Strategy and Leadership & 97 \\
\hline Ramaswamy V. & $\begin{array}{l}\text { Co-creating value through customers' experiences: } \\
\text { The Nike Case }\end{array}$ & 2008 & Strategy and Leadership & 89 \\
\hline $\begin{array}{l}\text { Slåtten T., } \\
\text { Mehmetoglu M. }\end{array}$ & $\begin{array}{l}\text { Antecedents and effects of engaged frontline } \\
\text { employess: a study from the hospitality industry }\end{array}$ & 2011 & $\begin{array}{l}\text { Managing Service } \\
\text { Quality }\end{array}$ & 88 \\
\hline $\begin{array}{l}\text { Hartley J., Sørensen } \\
\text { E., Torfing J }\end{array}$ & $\begin{array}{l}\text { Commaborative Innovation: a viable alternative to } \\
\text { market competition and organizational } \\
\text { entrepreneurship }\end{array}$ & 2013 & $\begin{array}{l}\text { Public Administration } \\
\text { Review }\end{array}$ & 77 \\
\hline $\begin{array}{l}\text { Salter A., Crisculo } \\
\text { P., Ter Wal A.L.J. }\end{array}$ & $\begin{array}{l}\text { Coping with open innovation: Responding to the } \\
\text { challenges of external engagement in } R \& D\end{array}$ & 2014 & $\begin{array}{l}\text { California Management } \\
\text { Review }\end{array}$ & 48 \\
\hline Bhatnagar J. & $\begin{array}{l}\text { Management of innovation: role of Psychological } \\
\text { empowerment, work engagement and turnover } \\
\text { intention in the Indian context }\end{array}$ & 2012 & $\begin{array}{l}\text { International Journal of } \\
\text { Human Resource } \\
\text { Management }\end{array}$ & 47 \\
\hline
\end{tabular}


Going more into detail on the descriptive analysis of the document's sample, further considerations can be made about the methodology adopted and the subject of the engagement in the research.

As reported in Figure 2, the studies have been classified as quantitative (studies based on survey and statistical inferences), qualitative (studies based on methodologies such as case study or ethnographic research), and conceptual). From the descriptive analysis emerges how the distribution of the three categories is quite homogeneous, although quantitative studies are more numerous. One last analysis focuses on the "subjects" of the engagement. In particular, the studies focus on two main categories: internals or externals to the organization. On the one side, the internal ones are employees or managers, and the focus is on innovation within their organization. On the other, there are external players, such as customers or stakeholders, that the company aims to engage in the innovation process. Figure 2 shows the distribution of the two categories across the overall sample and let emerge how most of the studies are focused on internals to the organization.

\section{Co-citation}

In the co-citation analysis (Figure 3), besides representing the original papers that have contributed to the literature of Engagement - Innovation relationship, four clusters emerge, showing different academic streams that represent the roots of the research on commitment in innovation:

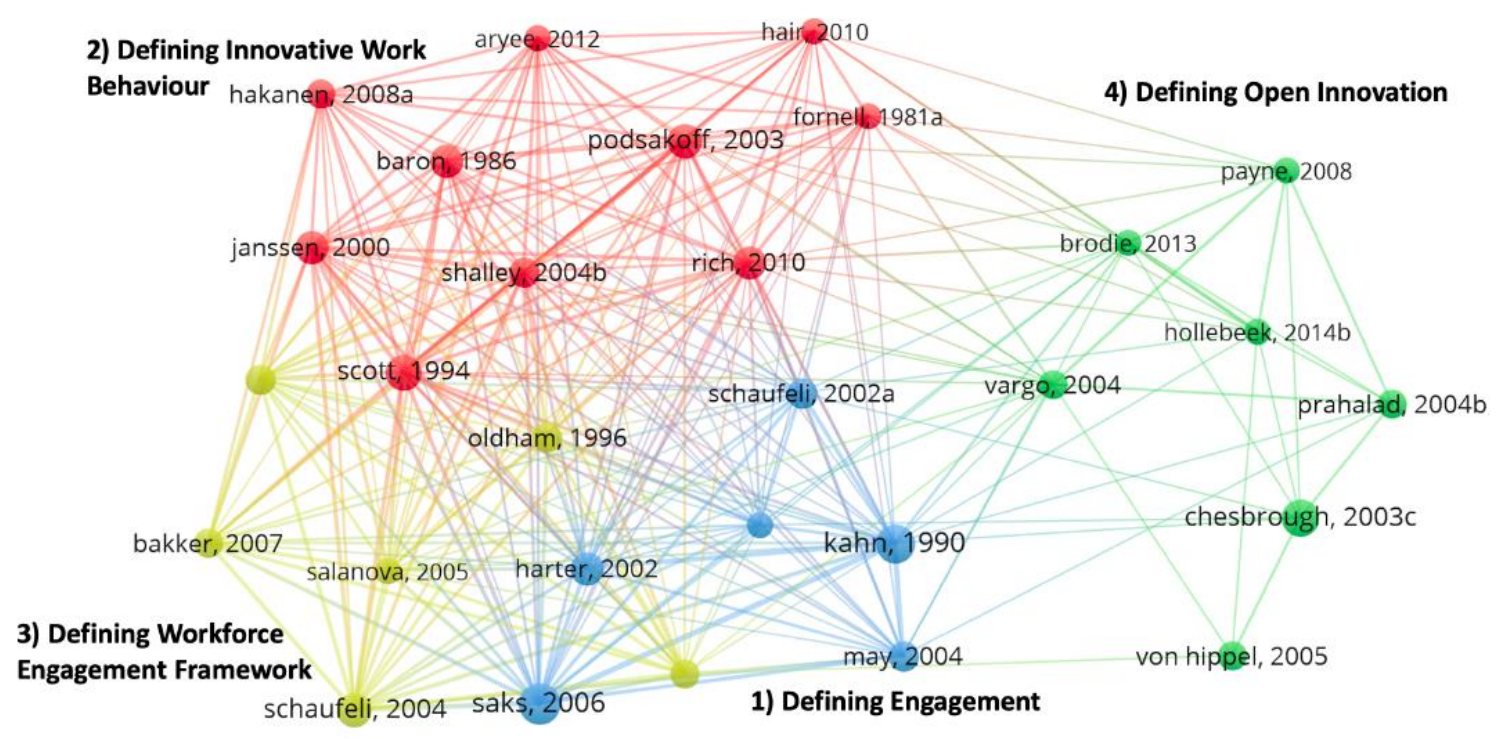

Figure 3 - Output of co-citation analysis on the whole sample of 105 papers with minimum citations count equal to 6

Table 2 briefly summarizes and presents the paper of each cluster.

It is essential to note the very high distance of the fourth cluster to the others, indicating the high gap recognized by the algorithm between the first three clusters (dealing with something internal to companies) and this last one (Van Eck and Waltman, 2014). It seems that two main areas exist among the roots of Engagement in innovation. On the one hand, papers are building on Engagement's subjective view, leveraging the original definitions of Engagement mentioned at the beginning, taking a work behavior perspective, and dealing mainly with the employees. On the other, research on Engagement in innovation deals with open innovation, moving the attention outside the company's borders. 
The blue cluster defines Engagement as the harnessing of organizational members' selves to their work roles, through their physical, cognitive, and emotional expression during their performances. It contains five papers dealing with the original conceptualizations of Engagement (Kahn 1990, Schaufeli et al., 2002), its antecedents, and outcomes (Harter et al., 2002, May 2004, Saks 2006).
The yellow cluster indicates the employees' willingness and ability to invest their effort in the success of the organization. It contains two papers aiming at verifying the correlation between high levels of employee engagement and enhanced performances with the mediation of organizational learning environment (Salanova et al., 2005) or creativity (Oldham and Cummings, 1996). Furthermore, the cluster contains another paper verifying the negative correlation between Engagement and burnout (Schaufeli and Bakker, 2004) and one dealing with a Human Resource model to foster employee engagement (Bakker and Demerouti, 2007)
The red cluster includes Engagement as an intentional behavior of an individual to introduce and apply new ideas, products andprocesses, to her work, unit, or organization. This cluster includes innovative work behavior antecedents both under an organizational perspective (Janssen 2000; Aryee et al. 2012), then under an individual viewpoint (Scott and Bruce, 1994; Shalley et al., 2004; Rich et al., 2010). The cluster also contains a paper dealing with the conception of the process through which high engagement levels bring to innovative work behaviors (Hakanen et al., 2008); finally, there are four papers which focus on measurement, using both Engagement and innovative work behaviors (Fornell and Larcker, 1981; Baron and Kenny, 1986; Podsakoff et al., 2003; Hair et al., 2010)
The green cluster broadens the concept of Engagement in an opposite way to the rest of the network, addressing issues outside the company. For open innovation, it is intended the use of purposive inflows and outflows of knowledge to accelerate internal innovation and expand the markets for external use of change, respectively (Chesbrough, 2003). This cluster includes the seminal paper introducing the concept of open innovation (Chesbrough, 2003), alongside articles dealing more specifically with the importance of engaging customers, consumers or users in innovation processes (Vargo and Lusch 2004; Von Hippel 2005; Payne et al., 2008; Prahalad and Ramaswamy, 2004; Brodie et al., 2013; Hollebeek et al., 2014).

Table 2 -Description of the four clusters

Therefore, we used the emergence of these two views on the topic to divide our sample into two sub-samples. Still, these two clusters deal - generally - with different kinds of players, but, on top of that, they have significant differences in how they consider the concept of Engagement.

The first is related to the study of people and organizational behavior towards Engagement. Therefore, it has been labeled as "Engagement as an attitude" and includes clusters blue red and yellow. The subsample involves all those studies that explore, from the people's perspective, how Engagement is directly related to individuals' mindset, and provide insights to harm or enhance such a behavioral phenomenon. According to this, within this cluster, it is possible to distinguish two main kinds of studies: those more focused on people's dynamics as a human being ("Human Perspective") and those more focused on organizational dynamics ("Organization Perspective").

The second includes those studies focused on Engagement as a collaboration with other players, which could be even external to the company, and regards only the green cluster. This cluster has been labeled as "Engagement as involvement," given that it deals with concepts of co-innovation as the result of collaborative efforts between either employees or agents external to the company. Here Engagement is meant as "involvement" of stakeholders more than "engagement" as originally 
intended in this study; moreover, innovation does not generate through the Engagement as a specific state of mind but instead through the collaboration of different actors that allows the integration of competencies, knowledge, and perspectives.

Therefore, we clustered the papers in the sample according to these labels, having 35 papers regarding the first one and 73 regarding the second. On them, we re-run the co-citation analysis.
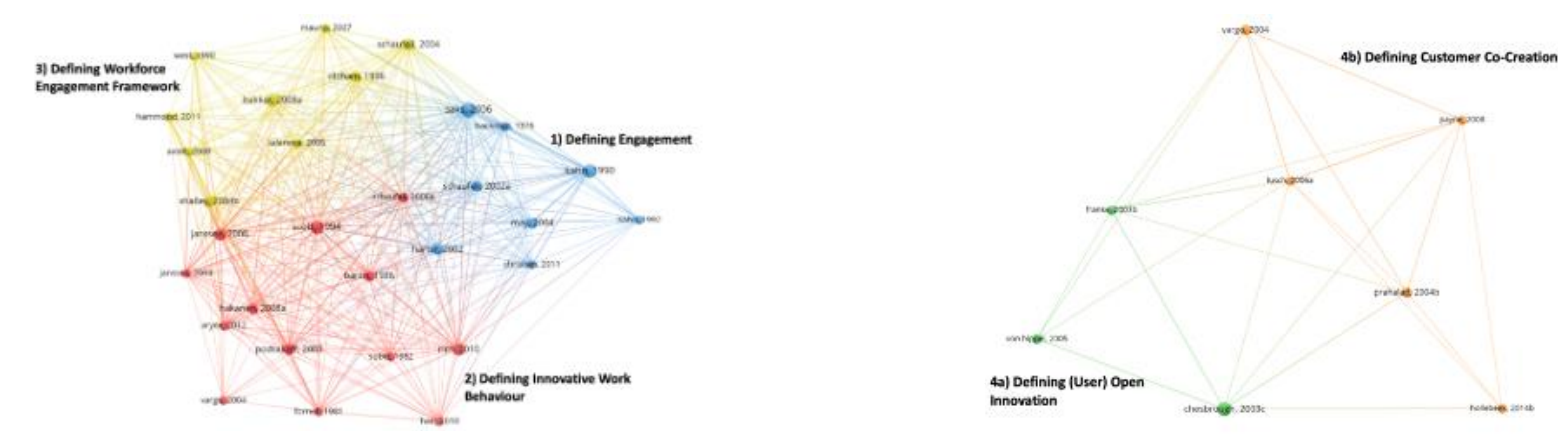

Figure 4 - Output of co-citation analysis on the whole subsample of 35 "Attitude"-labeled papers with minimum citations count equal to 5 and Output of co-citation analysis on the whole subsample of 73 "Involvement"-labeled papers with minimum citations count equal to 5

The co-citation network resulting from the "Engagement as an Attitude" category shown in Figure 4 immediately highlights the absence of the last cluster previously defined dealing with an extension of the engagement concept externally the company boundaries.

1. The blue cluster ("Defining Engagement") complements the insight drafted for the first analysis, adding another paper dealing with Engagement, its antecedents, and outcomes conceptualization (Christian 2011). It also contains two papers dealing with slightly different concepts: the former (Kahn 1992) conceptualizing psychological presence at work, and the latter (Hackman and Oldham, 1976) dealing with a similar but narrower conceptualization to the academic introduction.

2. The red cluster ("Defining Innovative Work Behavior") follows the previously defined logic, including this time two papers dealing with the definition of innovative work behavior as a consequence of Engagement (Janssen, 2003) and mathematical rules to validate models (Sobel 1982).

3. Finally, the yellow cluster ("Defining Workforce Engagement Framework") is added with two papers (Mauno et al., 2007; Bakker et al., 2008) dealing with the relationship between Engagement, job demand, and job resources and three (West and Farr 1990; Axtell et al., 2000; Hammond et al., 2011) dealing with predictors and antecedents to innovative work behavior.

Regarding the green cluster, the analysis performed only using "Engagement as Involvement shown in Figure 4, shows two different clusters that contain the same nodes encompassed by the green cluster labeled "Defining Open Innovation." 
4a. The Chesbrough (2003) seminal work on the open innovation paradigm is by far the most representative work within the network, indicating open innovation as the main academic foundation of "Engagement as Involvement" sub-sample of papers. It appears in the same cluster named "Defining (User) Open Innovation" together with two papers dealing with the importance of engaging users in open innovation processes (Franke and Shah, 2003; Von Hippel 2005).

4b. The other cluster instead ("Defining Customer Co-Creation") deals with four papers defining the value and the proper management of co-creation processes with customers (Vargo and Lusch, 2004; Payne et al., 2008; Prahalad and Ramaswamy 2004; Hollebeek et al., 2014).

The analysis also confirms that the reference literature related to the "Engagement as Involvement" papers' field is much less concentrated than reference literature related to the "Engagement as an Attitude" papers' field, being its network much weaker.

The analyses reveal that the theoretical basis of the research on the relationship between Engagement and innovation remains within the research field itself when considering both categories of papers. Nonetheless, references remain proxies for concepts' analysis, so that the text mining analysis has been performed to provide also a detailed analysis of the concept underlying in the set of papers chosen.

\section{Text mining}

This methodology has been used to approach a deeper level of analysis by decoding topics on which the literature has been focused. The output of the analysis consists of overlapping bubbles representing different themes encompassing concepts sharing a related meaning; the circle size indicates how many concepts have been clustered together to form a given theme. Text mining analysis has been performed on the two sub-samples above, respectively, the "Engagement as an Attitude" and the "Engagement as Involvement" sets of papers.

\section{Engagement as Involvement}

The analysis of the 73 paper through the text-mining algorithm (Figure 5) let immediately identifies "co-Innovation" concept, defined as a paradigm "where internal, external, collaborative, co-creative ideas can converge to create shared organizational value" (Lee et al., 2012), as the dominant topic which can indeed be studied taking an (i) external or (ii) internal perspective to the company. 


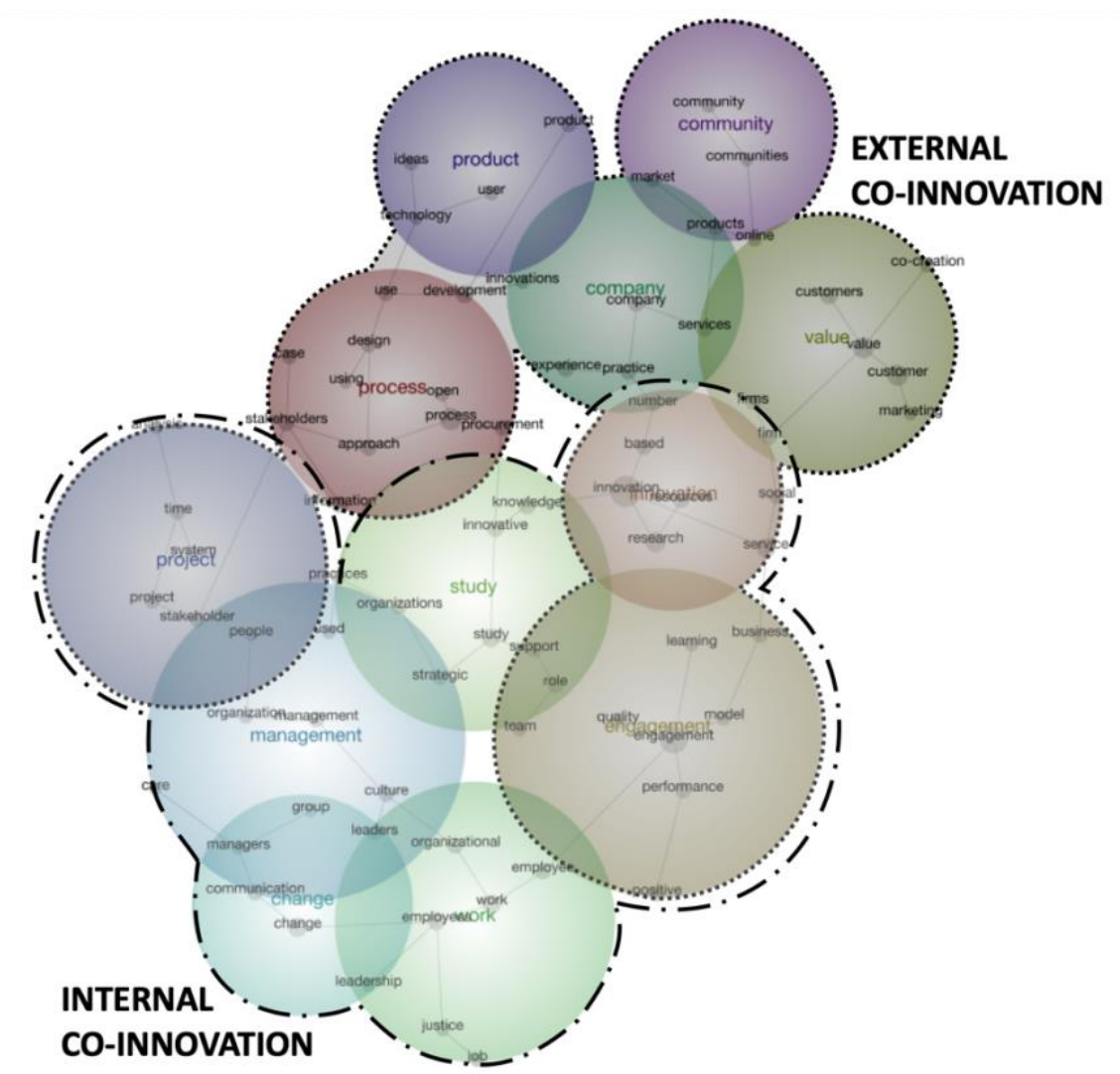

Figure 5 - Output of text mining analysis on the whole subsample of "Involvement "clustered papers

The first macro-cluster of papers ("External Co-Innovation Perspective") represents the different company-external factors enabling a co-innovation paradigm along with the definition of the process design (Table 3 ).

Three micro-themes emerge from the representation, including each one or more bubbles, such as Engagement, Stakeholders (Community \& Company \& Value), and Innovation (Innovation \& Process \& Product \& Project).

\begin{tabular}{|c|c|c|}
\hline $\begin{array}{l}\text { Macro- } \\
\text { cluster }\end{array}$ & Micro-themes & Brief description \\
\hline \multirow{2}{*}{ 苞 } & Engagement & $\begin{array}{l}\text { This theme deals with the definition of critical concepts of external stakeholders' } \\
\text { involvement in co-innovation projects. More specifically, with the definition of } \\
\text { different external actors' engagement levels: the very first level is to make the external } \\
\text { actor get the right mindset to build a partnership with the company in charge of the co- } \\
\text { innovation project; at that point, the third level is approached when the conversation } \\
\text { between the actor and the company starts, after which the co-innovation effort begins } \\
\text { to create advantages to the company (Salter et al., 2014). Companies are expected to } \\
\text { learn from these co-innovation activities engaging external stakeholders (Ramaswamy, } \\
\text { 2008; Agarwal and Selen, 2009; Ramaswamy, 2009; Ramaswamy, 2010; Nicolajsen } \\
\text { and Scupola, 2011; Rossi, 2011) which would subsequently allow enhancing corporate } \\
\text { innovation performances (Agarwal and Selen, 2009; Randall et al. 2013; Lee et al., } \\
\text { 2015; Chen et al., 2016). }\end{array}$ \\
\hline & $\begin{array}{l}\text { Stakeholders } \\
\text { (Community \& } \\
\text { Company \& } \\
\text { Value) }\end{array}$ & $\begin{array}{l}\text { The second theme deals with the definition of the sources of value of an external co- } \\
\text { innovation project: they can be customers, users, stakeholders, online communities, or } \\
\text { other companies, all contributing to create value within co-innovation efforts (Sawhney } \\
\text { et al., 2005; Ramaswamy 2008; Ramaswamy 2009; Ramaswamy 2010; Nicolajsen et } \\
\text { al., 2011; Rossi, 2011; Randall et al., 2013; Lee et al., 2014; Roberts et al., 2014; }\end{array}$ \\
\hline
\end{tabular}




\begin{tabular}{|c|c|}
\hline & $\begin{array}{l}\text { Wid.n et al., 2014; Zhang et al., 2015; Kavaliova et al., 2016; Oyner and Korelina, } \\
\text { 2016; Fernandes and Remelhe, 2016; Hollebeek and Andreassen, 2018). Some authors } \\
\text { also investigated why these stakeholders engage in co-innovation projects (Roberts et } \\
\text { al., 2014; Zhang et al., 2015; Fernandes and Remelhe, 2016). }\end{array}$ \\
\hline $\begin{array}{l}\text { Innovation } \\
\text { (Innovation \& } \\
\text { Process \& } \\
\text { Product \& } \\
\text { Project). }\end{array}$ & $\begin{array}{l}\text { The third topic deals with the definition of different innovation contexts considered } \\
\text { and underlying processes involved, as well as with the management of external } \\
\text { stakeholders. More specifically, engaging external stakeholders enhances performances } \\
\text { of service innovation (Agarwal and Selen, 2009; Chen et al., 2016; Heiskanen and } \\
\text { Matschoss, 2016, Oyner and Korelina, 2016), product and technology innovation } \\
\text { (Sawhney et al., 2005; Füller, 2006; Ramaswamy, 2008; Ramaswamy, 2009; Rossi, } \\
\text { 2011; te Kulve and Rip, 2011; Gr.nroos and Helle, 2012; Bogers and Horst, 2014; } \\
\text { Chen et al., 2016; Fernandes and Remelhe, 2016; Heiskanen and Matschoss, 2016; } \\
\text { Kavaliova et al., 2016), and impacting social innovations (Lee et al., 2012; Herrera, } \\
\text { 2015; Herrera, 2016; Torvinen and Ulkuniemi 2016; Watson et al., 2018). Finally, it } \\
\text { deals with the management of an external co-innovation effort, remarking how } \\
\text { "without organizational capabilities that align outside-in customer-to-employee } \\
\text { experience with inside-out employee-to customer experience, co-creation of value with } \\
\text { clients would be difficult to achieve" (Ramaswamy, 2009); companies should indeed } \\
\text { foster also internal actors' involvement in order to support the process of external } \\
\text { knowledge interiorization (Nowak, 2018; Tirabeni and Soderquist, 2018). }\end{array}$ \\
\hline
\end{tabular}

Table 3 - Summary of the External co-innovation cluster

The second macro-cluster, named "Internal Co-Innovation Perspective" is differentiated from the first one as co-innovation is now intended to occur within the boundaries of companies (Table 4). This second cluster lets emerge three micro-themes within the representation, including each one or more bubbles, such as Engagement, Innovation Management (Study \& Management \& Project), Employee (Work \& Change).

\begin{tabular}{|c|c|c|}
\hline $\begin{array}{l}\text { Macro- } \\
\text { cluster }\end{array}$ & $\begin{array}{l}\text { Micro- } \\
\text { themes }\end{array}$ & Brief description \\
\hline \multirow{3}{*}{ 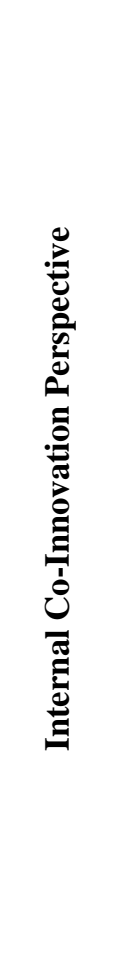 } & Engagement & $\begin{array}{l}\text { This cluster is shared between the two theme-clusters, and it deals with the definition of } \\
\text { different frameworks to engage internal actors in co-innovation projects (Tirabeni and } \\
\text { Soderquist, 2018). }\end{array}$ \\
\hline & $\begin{array}{l}\text { Innovation } \\
\text { Management } \\
\text { (Study \& } \\
\text { Management } \\
\text { \& Project) }\end{array}$ & $\begin{array}{l}\text { It defines how internal co-innovation should be managed at the organizational level: a pre- } \\
\text { condition to be successful is that the entire workforce comprehending both employees and } \\
\text { leaders is aligned (Ramaswamy, 2009); leaders can achieve this workforce alignment } \\
\text { (Smith, 1994; Hill et al., 2014; dle Zulueta, 2016; Li et al., 2018; Petrou et al., 2018) } \\
\text { setting up the right organizational culture (Smith, 1994; Michaelides, 2011; Petrou et } \\
\text { al.,2018; Snyder et al., 2018) through the creation of a sense of purpose, values, and rules } \\
\text { of engagement within the organization (Hill et al., 2014) along with the application of a } \\
\text { compassionate leadership style (dle Zulueta, 2016). The culture resulting from this effort } \\
\text { has been found to make internal co-innovation projects successful (de Weerd-Nederhof et } \\
\text { al., 2007; Kash et al., 2014; Totterdill and Exton, 2014; Nowak, 2018). }\end{array}$ \\
\hline & $\begin{array}{l}\text { Employee } \\
\text { (Work \& } \\
\text { Change) }\end{array}$ & $\begin{array}{l}\text { It deals with the organizational management of internal co-innovation but approaches a } \\
\text { deeper level of detail, emphasizing only the figure of the employee. More specifically, the } \\
\text { effectiveness of communication between employees and management (Rumbles and } \\
\text { Rees,2013; Kash et al., 2014; Butt et al., 2016; Ruck et al., 2017; Stachová et al., 2017; } \\
\text { Petrou et al., 2018) and the perceptions of justice on the job place (Fuchs and Edwards, } \\
\text { 2012) highly influence the workforce willingness to be engaged into co-innovation } \\
\text { processes. }\end{array}$ \\
\hline
\end{tabular}


Table 4 - Summary of the Internal co-innovation cluster

\section{Engagement as an attitude}

The two outputs performed on "Engagement as an Attitude" papers shown in Figure 6 profoundly differs from the parallel result for "Engagement as Involvement" papers. The word "Innovation" takes for this category ("Attitude") a more individualistic meaning, intending the capacity to generate, promote and realize ideas namely innovative work behavior (Chughtai and Buckely, 2011; Bhatnagar, 2012; Maria Stock et al., 2017; Jena and Memon, 2018; Jung and Yoon, 2018; Pham-Tai et al., 2018) as well as the capacity to recognize and to solve inefficiencies through the introduction of new solutions (De Spiegeleare et al., 2015; Garg and Dhar, 2017).

Engagement covers a fundamental role representing an attitude whose manifestation is making people capable of "thinking out-of-the-box and becoming open-minded," generating innovative solutions (Eldor, 2017). Due to the individualistic nature of the type of innovation studied and to the focus mainly within the company boundaries, the output displays much more interconnected network respect to the previous one. Specifically, the analysis pointed out two different clusters associated with a "Human perspective" and an "Organization perspective".

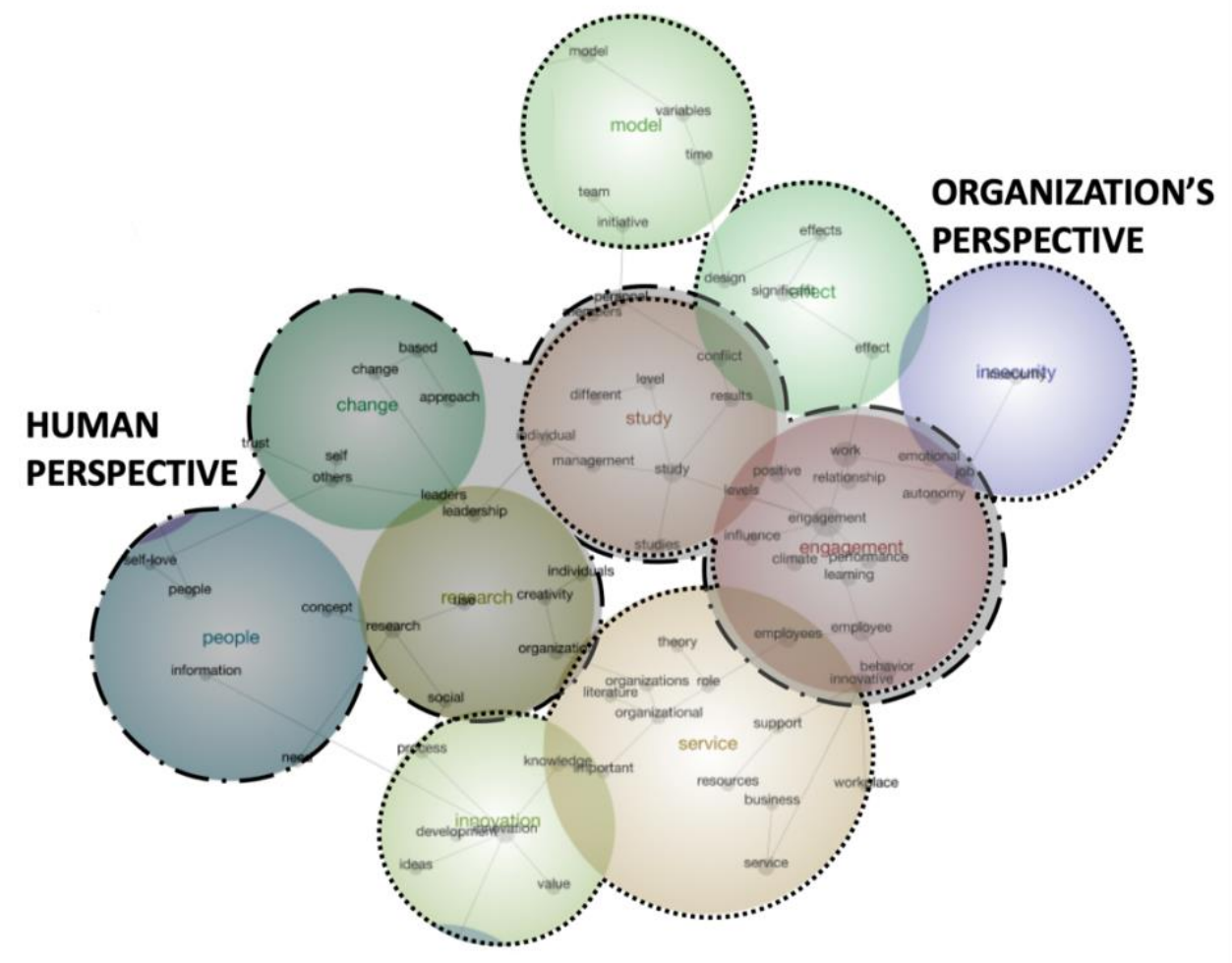

Figure 6 - Output of text mining analysis on the subsample of "Attitude"-labeled papers

The first cluster, representing the "Organization Perspective", deepens specifically the influence that the organization could have on employee engagement dynamics and therefore on employee's innovativeness. 


\begin{tabular}{|c|c|c|}
\hline $\begin{array}{l}\text { Macro- } \\
\text { cluster }\end{array}$ & $\begin{array}{l}\text { Micro- } \\
\text { themes }\end{array}$ & Brief description \\
\hline \multirow{3}{*}{ : } & $\begin{array}{c}\text { Engagement } \\
\text { (Engagement } \\
\text { and Study) }\end{array}$ & $\begin{array}{l}\text { This cluster explains the antecedents and outcomes of the concept of engagement: all the } \\
\text { papers analyzed rely on one or more of the popular definitions previously introduced as } \\
\text { Kahn (1990) or Schaufeli and Bakker (2004). Coming to the concept's antecedents within } \\
\text { the relationship, they range from individual to managerial aspects (Schraub et al., 2014; } \\
\text { Jung and Yoon, 2018, Tuzovic et al., 2018); specifically for the latter work climate and job } \\
\text { autonomy are encompassed as major variables individuated by authors (Chugthai and } \\
\text { Buckely, 2011; Slåtten and Mehmetoglu, 2011; De Spiegelaere et al., 2014; De Spiegelaere } \\
\text { et al., 2015; Kumar and Raghavendran, 2015; Orth and Volmer, 2017; Garg and Dhar,2017; } \\
\text { Eldor, 2017; Jung and Yoon, 2018; Pham-Thai et al., 2018; Tuzovic et al., 2018). Finally, } \\
\text { the different outcomes of engagement are highlighted: the likely outcomes are employee } \\
\text { innovative work behaviors along with an enhancement of employee performances } \\
\text { (Putkonen, 2009; Ayuso et al., 2011; Chugthai and Buckely, 2011; Grissemann et al., 2013; } \\
\text { Ehin, 2013; De Spiegelaere et al., 2014; De Spiegelaere et al., 2015; Kumar and } \\
\text { Raghavendran, 2015; Roll et al., 2015; Maria Stock et al., 2017; Orth and Volmer, 2017; } \\
\text { Eldor, 2017; Garg and Dhar, 2017; Jung and Yoon, 2018; Jena and Memon, 2018). }\end{array}$ \\
\hline & $\begin{array}{l}\text { Innovation } \\
\text { (Innovation } \\
\text { and Service) }\end{array}$ & $\begin{array}{l}\text { This cluster deals with the organizational management of innovation at a deeper level of } \\
\text { detail, emphasizing the importance of the employee (Chugthai and Buckely, 2011; } \\
\text { Bhatnaghar, 2012; De Spiegelaere et al., 2014; De Spiegelaere et al., 2015; Gomes et al., } \\
\text { 2015; Koch et al., 2015; Roll et al., 2015; Barata, 2016; Maria Stock et al., 2017; Merrilees } \\
\text { et al., 2017; Orth and Volmer, 2017; Eldor, 2017; Jung and Yoon, 2018; Jena and Memon, } \\
\text { 2018; Pham-Thai et al., 2018). It defines the service industry as the context within which } \\
\text { the relationship between engagement and innovation has been studied the most, with the } \\
\text { tourism industry the one mostly investigated (Slåtten and Mehmetoglu, 2011; Grissemann } \\
\text { et al., 2013; Jung and Yoon, 2018). }\end{array}$ \\
\hline & $\begin{array}{l}\text { Workforce } \\
\text { (Insecurity, } \\
\text { Conflict and } \\
\text { Model)) }\end{array}$ & $\begin{array}{l}\text { It defines how the relationship between Engagement and innovation can be influenced also } \\
\text { by different negative organizational variables (Putkonen, 2009; De Spiegelaere et al., 2015) } \\
\text { such as job insecurity (De Spiegelaere et al., 2014; Roll et al., 2015) or conflict management } \\
\text { (Scharub et al., 2014; Jung and Yoon, 2018). }\end{array}$ \\
\hline
\end{tabular}

Table 5 - Summary of Organization perspective cluster

The second cluster, on the "Human Perspective", frames the concept of innovation, identifying the common processes that are influenced from high engagement levels, named idea creation, promotion, and implementation.

\begin{tabular}{|c|c|c|}
\hline $\begin{array}{l}\text { Macro- } \\
\text { cluster }\end{array}$ & $\begin{array}{l}\text { Micro- } \\
\text { themes }\end{array}$ & Brief description \\
\hline \multirow{2}{*}{ 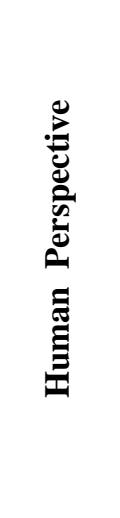 } & $\begin{array}{l}\text { Engagement } \\
\text { (Engagement) }\end{array}$ & $\begin{array}{l}\text { This first cluster is the central node between the two perspectives, i.e. the organizational } \\
\text { and the human ones, and it includes all the text of papers explaining the different } \\
\text { definitions of engagement used within the document. }\end{array}$ \\
\hline & $\begin{array}{l}\text { Social } \\
\text { Relationships } \\
\text { (People and } \\
\text { Change) }\end{array}$ & $\begin{array}{l}\text { It deals with the deepest human factors that can influence engagement and therefore } \\
\text { innovation output; they are either personal factors or factors related to a social relationship: } \\
\text { to start with, to love own-self is a fundamental condition to be engaged and for leaders to } \\
\text { engage subordinates (Maharaj and April, 2013); secondly, leaders are fundamental to make } \\
\text { employees engaged and to make them foster innovation, (Holten and Brenner, 2015; } \\
\text { Gomes et al., 2015; Barata, 2016; Garg and Dhar, 2016; Pham-Thai et al., 2018) and in } \\
\text { their relationship with subordinated trust is necessary (Chughtai and Buckely, 2011; Jena } \\
\text { and Memon, 2017). }\end{array}$ \\
\hline
\end{tabular}




\begin{tabular}{|l|l|l|}
\hline & & $\begin{array}{l}\text { This cluster emphasiesthe importance of learning process of the employee. It } \\
\text { summarizes what are the variables to be studied within the relationship that starts with } \\
\text { engagement and has innovation-related outcomes. At one side of the relationship, the } \\
\text { players who potentially influence the relationship's output are employees, leaders, the } \\
\text { management, and the organizational culture. At the other side of the relationship, } \\
\text { creativity has been found to mediate the relationship between engagement and innovation } \\
\text { (Slåtten and Mehmetoglu, 2011; Kumar and Raghavendran, 2015; Garcia Martinez, } \\
\text { 2015; Koch et al., 2015; Orth and Volmer, 2017). } \\
\begin{array}{c}\text { Knanagement } \\
\text { (nesearch and } \\
\text { Innovation) }\end{array}\end{array}$ \\
\hline
\end{tabular}

Table 6 - Summary of Human perspective

\section{Discussion}

\section{Engagement and Innovation: a relationship evolving over time}

The two outputs performed on "Engagement as an Attitude" papers shown in Figure 6 profoundly differs from the parallel result for "Engagement as Involvement" papers. The word "Innovation" takes for this category ("Attitude") a more individualistic meaning, intending the capacity to generate, promote and realize ideas namely innovative work behavior (Chughtai and Buckely, 2011; Bhatnagar, 2012; Maria Stock et al., 2017; Jena and Memon, 2018; Jung and Yoon, 2018; Pham-Tai et al., 2018) as well as the capacity to recognize and to solve inefficiencies through the introduction of new solutions (De Spiegeleare et al., 2015; Garg and Dhar, 2017).

This paper aims to understand how the literature sheds light on the relationship between Engagement and Innovation. We approached this goal with a systematic literature review, aiming to understand how scholars conceptualized and studied Engagement in innovation activities.

This analysis let emerge a strong time-dependency, showing how - in the last 30 years - the role and the meaning of Engagement changed significantly.

We need to go back at the beginning of the 90s to have one of the most accepted definitions of Engagement (Kahn, 1990), showing the various nuances of this concept. As anticipated in the second section of the paper, the roots of this concept come from the psychological world, defining the pure meaning of Engagement.

Still, if we move on in the years, we will have the chance to see two parallel evolution lines: innovation management changes and the perception of Engagement by innovation scholars that changes accordingly.

The last century's end has been characterized by two main streams of research in the innovation literature. On the one hand, scholars focused mainly on technological dynamics (e.g., Anderson and Tushman, 1990; Christensen and Bower, 1995), showing the main innovation trigger considered back in the days: technologies that enable new products, services, and processes.

On the other, innovation scholars were mainly interested in insights from the market, studying customers' needs (e.g., Von Hippel, 1986).

The technical roots of innovation management studies may be behind the lack of studies dealing with Engagement back in the days, if not with some initial studies related - for example - to the alignment with the employees (Smith, 1994). Innovation was related to a specific job position, being in the R\&D, or the marketing function. 
The new century saw the rise of what is still considered the leading paradigm for innovation studies: Open Innovation. Chesbrough (2003) proposed a different view to see innovation activities. Innovation should not be confined to a specific function, and even more: it should not be confined within the organization boundaries. After some years - the time to let Open Innovation become the leading paradigm (e.g., Chesbrough et al., 2020) - innovation scholars start paying attention to how "engage" people in the innovation process, privileging the "involvement" nature of Engagement. As previously mentioned, this concerns both people within the firm (e.g., de Weerd-Nederhof et al., 2007; Ramaswamy, 2009; Michaelides, 2011) and people outside the firm, other stakeholders (e.g., Sawhney et al., 2005; Ramaswamy, 2008).

Therefore, we may suggest a strong parallelism between the rise of the OI paradigm and the focus on the rise of the "Engagement as Involvement" stream. This is highly coherent even with the two sub-clusters emerging from our results ("External Co-Innovation Perspective" and "Internal CoInnovation Perspective"). The literature at the intersection between engagement and innovation seems to embrace the main OI message focusing on the involvement of any players that may benefit to the innovation process, both within and outside the firm's boundaries.

Still, in the following years, the world and the innovation's issues emerged. Innovation now has an engagement issue: some people join the innovation process, but that is not their primary job, so we need to find ways to engage them.

At the beginning of the last decade, we see the emergence of an individual perspective at the intersection between Engagement and innovation. It is not just a matter of being engaged in the company's innovation process. It is a matter of having the chance to foster innovation at work. This goes along with the study of a higher level of autonomy - for example - to increase the engagement level (Arrowsmith and Parker, 2013). This is highly coherent with the emergence of employee-driven innovation (e.g., Høyrup, 2010). Engagements seem to be linked with "job design," being engaged by having a more active role in what you do as an individual within the company (e.g., De Spiegelaere et al., 2014; De Spiegelaere et al., 2015).

The end of the 00s' saw the rise of the design-driven literature in management studies, with the initial rise of design thinking (Brown, 2009). The design was meant to support the innovation process by encouraging wild ideas and finding new possible innovations. Still, over the years, it proved to be a great tool to let individuals discover and foster their creativity and creative confidence (Kelley and Kelley, 2013; Dell'Era et al., 2020). Scholars start suggesting that the relationship between Engagement and innovation indeed can be mediated by individual creativity (Garcia Martinez, 2015; Koch et al., 2015; Kumar and Raghavendran, 2015). This movement towards the "confidence" in doing innovation shows the substantial shift from a view on Engagement as "pure involvement" to an actual attitude. Engagement in innovation means having the right attitudes, contributing to a cultural dimension (e.g., Kumar and Raghavendran, 2015; Koch et al., 2015; Howaldt et al., 2016). The last evidence let emerge a final shift from the organizational culture to the organizational climate (Jena and Memon, 2018; Pham-Thai et al., 2018; Tuzovic et al., 2018). People need to feel to be in the right place to foster innovation.

This is coherent with the latest developments in the innovation field. On the one hand, we see the rise of agile approaches that go beyond the process and enter the organizational dynamics. Agility is not anymore just a matter of project management; it is a matter of setting an organizational climate where people perceive the opportunity to foster continuous innovation (e.g., Bäcklander, 2019). On the other, we see the rising need for new directions rather than solutions, and this has a secure connection with the organizational climate. We live in a world overcrowded by ideas; to be innovative, we need new directions that overcome the abundance of solutions with something truly meaningful (Bellis and Verganti, 2020; Verganti, 2017). In doing so, companies need to set the right 
climate to let people engage and offer their constructive views on the innovative direction through active criticism and building on the others (e.g., Bellis and Verganti, 2019; Verganti and Norman, 2019).

Therefore, we are proposing a strong parallelism between the latest evolutions of the innovation management landscape and the second cluster we see emerging in our analysis, the "Engagement as an Attitude". Once again, we can see a direct link between the sub-clusters emerging from the text mining analysis. The human side of this "attitude" is highly related to the individual perspective emerging in the innovation field (Arrowsmith and Parker, 2013), but also to the design-driven literature that sees the innovation process as an inside-out process that starts from the innovator as a human being (Verganti, 2017). Similarly, the second sub-cluster, which takes the organizational perspective, is highly correlated with the evolution that organizations are facing, from the agile culture (Bäcklander, 2019) to the need to have an organizational climate coherent with what innovation needs (Bellis and Verganti, 2019; Verganti and Norman, 2019).

In the current world, Engagement is not anymore just a matter of being involved in something; it is not even just a matter of the right "culture," it is a matter of an individual attitude that takes place in organizations with the right climate.

Innovation scholars, probably, still need to explore in-depth this kind of Engagement, and our work proposes a research agenda that may help in this direction.

Call for future research 
This critical review of the Engagement in innovation activities let emerge two things. On the one hand, the Engagement concept had a steady evolution over the years, mainly connected with the megatrends of the innovation field. At the same time, we can see (Figure 2) growing attention to the topic in the last decade, even though it remains a relatively small field.

Still, the latest trends in the innovation field - such the movements from solutions to meanings (Verganti, 2017) and from process-oriented models to people-oriented studies - anticipate a growing relevance of the Engagement of people in innovation activities. The reasonings at the basis of this paper suggest that innovation mangers, in the next years, will have to prove themselves able to engage people and create a proper culture in their organizations to foster innovation.

Therefore, we suggest a call for research to increase the focus on the human side of innovation, giving relevance to Engagement in innovation activities is proposed.

In particular, we suggest researchers to focus their attention on the basis of two different rationales. On the one hand - moving attention to people rather than processes -identifying as the unit of analysis: individuals, teams, or the organizations. On the other, addressing the kind of Engagement we want to target: "Engagement as Involvement" in the innovation activities or "Engagement as an Attitude."

The unit of analysis needs to be highly considered. How can we engage individuals in the innovation process? The design literature tells us a lot about the power of working on something, and we know that individual characteristics play a role in individual Engagement. Still, innovation managers need to understand what moves the employee, how the individual may be collectively engaged in innovative projects that he/she may not have conceived from the beginning. The same reasoning can shift to a higher level of aggregation. Indeed, innovation is often done through the involvement of various people. The leadership literature tells a lot about team dynamics, but again, how can innovation managers deal with the Engagement of a group of individuals working on the same project? Finally, there is also the organization's perspective that needs to be considered. The culture and the climate play a role in the Engagement of individuals within a complex social system like an organization. This level deserves particular attention as well.

These three layers should be matched and studied according to the type of Engagement we are dealing with.

"Engagement as an Attitude" needs to be further exploited through all these levels, and innovation managers still need a lot of answers. How can they stimulate Engagement in people? What are the behaviors that stimulate Engagement? What are the main drivers for Engagement? And the main barriers? How do "engaged" people behave? What are the typical interactions between "engaged" people? How can we present ideas, projects, and visions in engaging ways? What are the tools that enhance Engagement? These are just possible questions that innovation scholars should go through to enlarge the human side of innovation considered the Engagement of people while working on innovation projects.

Similar questions may be re-formulated looking at the other kinds of Engagement defined in this paper: "Engagement as Involvement". Not considering the personal attitude towards Engagement, we still need to understand how to involve people in innovation projects appropriately, and all the previous questions may be re-formulated with this goal in mind. 
This list of questions does not aim to be exhaustive anyhow; they represent a possible starting point to enlarge the current view of innovation studies aiming to take a broader human perspective.

Moreover, it is crucial to consider the changes also in the data gathering and data analysis techniques, rather than focusing only on how the innovation field changed. In other words, the vast majority of the studies in the article are based on self-reported measures analyzed through traditional statistical methods. Obviously, these methods proved the accuracy over the years and worth to be furthered explored. Nevertheless, we need to consider also alternative methods. Selfreported measures need to deal with various kinds of intrinsic biases, which may become even more relevant in dealing with Engagement. In our daily life, we create an enormous amount of data, from how we use our computer to what we write on social media and the digital services we enjoy. Digital data - created for different purposes rather than research - proved to be valuable for commercial and research purposes (Trabucchi and Buganza, 2019). Researchers may think about innovative ways also to measure Engagement - obviously in respect of all the data policies and privacy laws but developing methodological innovation in terms of data gathering and data analysis may open new and relevant ways to study how people behave in doing innovation.

Despite all the studies reported aims at framing the present literature into a model, our work is not without limitations. The research approach employed for gathering and selecting the reviewed studies may not totally avoid any loss of information, as relevant studies might have been excluded from the sample for inconsistency with the methodology applied. The authors are aware that applying to the study a more inclusive Scopus database, together with identifying a more detailed multi-step process could potentially enrich knowledge in the field for future development and possibly reduce the

accidental biases. Further insights on how to stimulate and assess engagement inside the organizations could foster the willingness to invest in such aspect for companies aiming at strengthening their purpose in producing more innovative products and organizations.

\section{Conclusion}

Nowadays, innovation pace is at its highest, reaching levels that make people feeling overwhelmed by innovation initiatives (Verganti, 2017). More and more often, people tend to link innovation with "danger", rather than "opportunity" (Zhexembayeva, 2020). Therefore, the engagement of people in innovation is one of the biggest challenges organizations are facing. This study offers a new view at the intersection between engagement and innovation. It explores the overlapping of these two streams and highlights what has been written and how it evolved coherently with the innovation management world.

Our study contributes to the current debate in two different ways. Taking an academic perspective, the chance to highlight the labels "Engagement as Involvement" and "Engagement as an Attitude" enhance the scholarly debate and offers a theoretical contribution that may push forward future research, as mentioned in the previous paragraph. The chance to distinguish between these two labels and the systematization of the literature may help the stream at the intersection between Engagement and Innovation to evolve building on these two perspectives. The present study identified what enables and defined the two "kinds" of engagement. Still, much more need to be explored about how to nurture and implement such engagement dynamics to sustain innovation and the people to make it happens. In the concluding part, our study proposes a research agenda that may help in this direction. 
Taking a practitioner perspective, this review helps innovation managers better understand what "engaging people in innovation" means. "Engagement as Involvement" and "Engagement as an Attitude" are both relevant as never before. It means that people need to feel not just an attitude towards innovation, but also to perceive to be part of the innovation process and to be in an environment with the right climate. This study has two main takeaways for managers. On the one hand, it helps them go deeper into the concept of engagement through the labels and the subclusters that highlight different perspectives and nuances. On the other hand, this study may offer a compass for them to find relevant studies that explore the various kinds of engagement, helping them in accessing and exploring the literature at the intersection between engagement and innovation.

\section{References}

Due to the great number of references, in the list there are only the references cited in the next, all the other are available upon request.

Alblooshi, M., Shamsuzzaman, M. and Haridy, S., (2020). The relationship between leadership styles and organisational innovation. European Journal of Innovation Management.

Alfes, K., Truss, C., Soane, E., Rees, C. \& Gatenby, M. 2010, "CIPD Research Report: Creating an Engaged Workforce", Chartered Institute of Personnel and Development, London.

Anderson, P. \& Tushman, M.L. 1990, "Technological discontinuities and dominant designs: A cyclical model of technological change", Administrative Science Quarterly, pp. 604-633.

Anitha, J. 2014, "Determinants of employee engagement and their impact on employee performance", International journal of productivity and performance management.

Antons, David, et al. "The application of text mining methods in innovation research: current state, evolution patterns, and development priorities." R\&D Management.

Arrowsmith, J. \& Parker, J. 2013, "The meaning of a employee engagement for the values and roles of the HRM function", The international journal of Human Resource management, vol. 24, no. 14, pp. 2692-2712.

Aryee, S., Walumbwa, F.O., Zhou, Q. \& Hartnell, C.A. 2012, "Transformational leadership, innovative behavior, and task performance: Test of mediation and moderation processes", Human Performance, vol. 25, no. 1, pp. 1-25.

Axtell, C.M., Holman, D.J., Unsworth, K.L., Wall, T.D., Waterson, P.E. \& Harrington, E. 2000, "Shopfloor innovation: Facilitating the suggestion and implementation of ideas", Journal of Occupational and Organizational Psychology, vol. 73, no. 3, pp. 265-285.

Bäcklander, G. 2019, "Doing complexity leadership theory: How agile coaches at Spotify practise enabling leadership", Creativity and Innovation Management, vol. 28, no. 1, pp. 42-60.

Bakker, A.B. \& Demerouti, E. 2007, "The job demands resources model: State of the art", Journal of Managerial Psychology, .

Bakker, A.B., Schaufeli, W.B., Leiter, M.P. \& Taris, T.W. 2008, "Work engagement: An emerging concept in occupational health psychology", Work \& stress, vol. 22, no. 3, pp. 187-200.

Baron, R.M. \& Kenny, D.A. 1986, "The moderator mediator variable distinction in social psychological research: Conceptual, strategic, and statistical considerations.", Journal of personality and social psychology, vol. 51, no. 6, pp. 1173.

Bellis, P., \& Verganti, R. 2020, "Pairs as pivots of innovation: how collaborative sensemaking benefits from innovating in twos", Innovation: Organization and Management, 1-25. 
Bellis, P. \& Verganti, R. 2019, "Pairs In Innovation: How Working In Pairs Helps Organizations To Move Into A New Shared Direction", International Journal of Innovation Management, vol. 24, n. 3.

Bessant, J. (2003). "Challenges in innovation management. In The international handbook on innovation" (pp. 761-774). Pergamon.

Bhatnagar, J. 2012, "Management of innovation: Role of psychological empowerment, work engagement and turnover intention in the Indian context", The International Journal of Human Resource Management, vol. 23, no. 5, pp. 928-951.

Biesenthal, C. \& Wilden, R. 2014, "Multi-level project governance: Trends and opportunities", International Journal of Project Management, vol. 32, no. 8, pp. 1291-1308.

Bogers, M. \& Horst, W. 2014, "Collaborative prototyping: Cross-fertilization of knowledge in prototype-driven problem solving", Journal of Product Innovation Management, vol. 31, no. 4, pp. 744-764.

Bower, J.L. \& Christensen, C.M. 1995, "Disruptive technologies: catching the wave" .

Brenton, B. \& Levin, D. 2012, "The softer side of innovation: The people", Journal of Product Innovation Management, vol. 29, no. 3, pp. 364-366.

Brodie, R.J., Ilic, A., Juric, B. \& Hollebeek, L. 2013, "Consumer engagement in a virtual brand community: An exploratory analysis", Journal of business research, vol. 66, no. 1, pp. 105-114.

Brown, T. 2008, "Design thinking", Harvard business review, vol. 86, no. 6, pp. 84-92+141.

Calabretta, G., Durisin, B. \& Ogliengo, M. 2011, "Uncovering the intellectual structure of research in business ethics: A journey through the history, the classics, and the pillars of Journal of Business Ethics", Journal of Business Ethics, vol. 104, no. 4, pp. 499-524.

Campbell, C., Pitt, L.F., Parent, M. \& Berthon, P.R. 2011, "Understanding consumer conversations around ads in a Web 2.0 world", Journal of Advertising, vol. 40, no. 1, pp. 87-102.

Chesbrough, H.W. 2003, Open innovation: The new imperative for creating and profiting from technology, Harvard Business Press.

Chesbrough, H. \& Tucci, C.L. 2020, "The Interplay between Open Innovation and Lean Startup, or, Why Large Companies are not Large Versions of Startups", .

Christensen, C. M. (1997). "The innovator's dilemma: When new technologies cause great firms to fail" Harvard Business Review Press.

Christian, M.S., Garza, A.S. \& Slaughter, J.E. 2011, "Work engagement: A quantitative review and test of its relations with task and contextual performance", Personnel Psychology, vol. 64, no. 1, pp. 89-136.

Chughtai, A.A. \& Buckley, F. 2011, "Work engagement", Career Development International, .

Cooper, R.G. 1990, "Stage-gate systems: a new tool for managing new products", Business horizons, vol. 33, no. 3, pp. 44-54.

De Spiegelaere, S., Van Gyes, G., De Witte, H. \& Van Hootegem, G. 2015, "Job design, work engagement and innovative work behavior: A multi-level study on Karasek's learning hypothesis", management revue, , pp. 123-137.

De Spiegelaere, S., Van Gyes, G., De Witte, H., Niesen, W., \& Van Hootegem, G. (2014). On the relation of job insecurity, job autonomy, innovative work behaviour and the mediating effect of work engagement. Creativity and Innovation Management.

Dell'Era, C., Magistretti, S., Cautela, C., Verganti, R., \& Zurlo, F. (2019) Four kinds of design thinking: From ideating to making, engaging, and criticizing. Creativity and Innovation Management.

Dvir, T., Eden, D., Avolio, B. J., \& Shamir, B. (2002). "Impact of transformational leadership on follower development and performance: A field experiment". Academy of management journal, vol. 45, no. 4, pp. 735-744. 
Eldor, L. 2017, "The relationship between perceptions of learning climate and employee innovative behavior and proficiency", Personnel Review, .

Fornell, C. \& Larcker, D.F. 1981, "Evaluating structural equation models with unobservable variables and measurement error", Journal of Marketing Research, vol. 18, no. 1, pp. 39-50.

Fortunato, S. \& Barthelemy, M. 2007, "Resolution limit in community detection", Proceedings of the national academy of sciences, vol. 104, no. 1, pp. 36-41.

Franke, N. \& Shah, S. 2003, "How communities support innovative activities: an exploration of assistance and sharing among end-users", Research policy, vol. 32, no. 1, pp. 157-178.

Füller, J. 2006, "Why consumers engage in virtual new product developments initiated by producers", ACR North American Advances, .

Garg, S. \& Dhar, R. 2017, "Employee service innovative behavior", International Journal of Manpower, .

Ghezzi, A., Gabelloni, D., Martini, A., \& Natalicchio, A. (2018). Crowdsourcing: a review and suggestions for future research.International Journal of Management Reviews, 20(2), 343-363.

Gmür, M. 2003, "Co-citation analysis and the search for invisible colleges: A methodological evaluation", Scientometrics, vol. 57, no. 1, pp. 27-57.

Hair, J.F., Black, W.C., Babin, B.J., Anderson, R.E. \& Tatham, R.L. (2010), Multivariate data analysis, Prentice hall Upper Saddle River, NJ.

Hakanen, J.J., Perhoniemi, R. \& Toppinen-Tanner, S. 2008, "Positive gain spirals at work: From job resources to work engagement, personal initiative and work-unit innovativeness", Journal of vocational behavior, vol. 73, no. 1, pp. 78-91.

Hammond, M.M., Neff, N.L., Farr, J.L., Schwall, A.R. \& Zhao, X. 2011, "Predictors of individual-level innovation at work: A meta-analysis.", Psychology of Aesthetics, Creativity, and the Arts, vol. 5, no. 1 , pp. 90.

Harter, J.K., Schmidt, F.L. \& Hayes, T.L. 2002, "Business-unit-level relationship between employee satisfaction, employee engagement, and business outcomes: a meta-analysis.", Journal of applied psychology, vol. 87, no. 2, pp. 268.

Hollebeek, L.D., Glynn, M.S. \& Brodie, R.J. 2014, "Consumer brand engagement in social media: Conceptualization, scale development and validation", Journal of interactive marketing, vol. 28, no. 2, pp. 149-165.

Howaldt, J., Oeij, P.R., Dhondt, S. \& Fruytier, B. 2016, "Workplace innovation and social innovation: an introduction", World Review of Entrepreneurship, Management and Sustainable Development, vol. 12, no. 1, pp. 1-12.

Høyrup, S. 2010, Employee-driven innovation and workplace learning: basic concepts, approaches and themes, .

Janssen, O. 2003, "Innovative behaviour and job involvement at the price of conflict and less satisfactory relations with coâ€?workers", Journal of Occupational and Organizational Psychology, vol. 76, no. 3, pp. 347-364.

Janssen, O. 2000, "Job demands, perceptions of effortâ€?reward fairness and innovative work behaviour", Journal of Occupational and Organizational Psychology, vol. 73, no. 3, pp. 287-302.

Jena, L.K. \& Memon, N.Z. 2018, "Does workplace flexibility usher innovation? A moderated mediation model on the enablers of innovative workplace behavior", Global Journal of Flexible Systems Management, vol. 19, no. 1, pp. 5-17.

Jung, H.S. \& Yoon, H.H. 2018, "Improving frontline service employees' innovative behavior using conflict management in the hospitality industry: The mediating role of engagement", Tourism Management, vol. 69, pp. 498-507. 
Kahn, W.A. 1992, "To be fully there: Psychological presence at work", Human relations, vol. 45, no. 4, pp. 321-349.

Kahn, W.A. 1990, "Psychological conditions of personal engagement and disengagement at work", Academy of management journal, vol. 33, no. 4, pp. 692-724.

Kelley, T., \& Kelley, D. 2013 Creative confidence: Unleashing the creative potential within us all. Currency.

Klaus, S. 2016, The fourth industrial revolution. In World Economic Forum, p. 11.

Koch, A.R., Binnewies, C. \& Dormann, C. 2015, "Motivating innovation in schools: School principals' work engagement as a motivator for schools' innovation", European Journal of Work and Organizational Psychology, vol. 24, no. 4, pp. 505-517.

Krishnan, V. \& Ulrich, K.T. 2001, "Product development decisions: A review of the literature", Management Science, vol. 47, no. 1, pp. 1-21.

Kumar, H. \& Raghavendran, S. 2015, "Gamification, the finer art: fostering creativity and employee engagement", Journal of Business Strategy, .

Lee, S.M., Olson, D.L. \& Trimi, S. 2012, "Co-innovation: convergenomics, collaboration, and cocreation for organizational values", Management decision, vol. 50, no. 5, pp. 817-831.

Lill, P., Wald, A., \& Munck, J. C. (2020). In the field of tension between creativity and efficiency: a systematic literature review of management control systems for innovation activities. European Journal of Innovation Management.

Magistretti, S., Dell'Era, C., \& Verganti, R. (2020). Searching for the right application: A technology development review and research agenda. Technological Forecasting and Social Change, 151, 119879.

Mainemelis, C. \& Ronson, S. 2006, "Ideas are born in fields of play: Towards a theory of play and creativity in organizational settings", Research in Organizational Behavior, vol. 27, pp. 81-131.

Maria Stock, R., Jong, A.d. \& Zacharias, N.A. 2017, "Frontline employees' innovative service behavior as key to customer loyalty: Insights into FLEs' resource gain spiral", Journal of Product Innovation Management, vol. 34, no. 2, pp. 223-245.

Martinez, M.G. 2015, "Solver engagement in knowledge sharing in crowdsourcing communities: Exploring the link to creativity", Research Policy, vol. 44, no. 8, pp. 1419-1430.

Mathies, C., and M. Burford. 2011, "Customer service understanding: gender differences of frontline employees", Managing Service Quality: An International Journal, vol. 21, no. 6, pp. 636-648.

Matzler, K., Friedrich von den Eichen, Stephan, Anschober, M. \& Kohler, T. 2018, "The crusade of digital disruption", Journal of Business Strategy, vol. 39, no. 6, pp. 13-20.

Mauno, S., Kinnunen, U. \& Ruokolainen, M. 2007, "Job demands and resources as antecedents of work engagement: A longitudinal study", Journal of vocational behavior, vol. 70, no. 1, pp. 149171.

Michaelides, D. 2011, "Will gamify those processes. The art of innovation in the public sector", International Journal of Innovation Science, .

Nemet, G.F. 2009, "Demand-pull, technology-push, and government-led incentives for nonincremental technical change", Research policy, vol. 38, no. 5, pp. 700-709.

Oldham, G.R. \& Cummings, A. 1996, "Employee creativity: Personal and contextual factors at work", Academy of management journal, vol. 39, no. 3, pp. 607-634.

Oldham, G. R., Hackman, J. R., \& Pearce, J. L. 1976, “Conditions under which employees respond positively to enriched work", Journal of applied psychology, vol. 61, n. 4, pp. 395.

Payne, A.F., Storbacka, K. \& Frow, P. 2008, "Managing the co-creation of value", Journal of the academy of marketing science, vol. 36, no. 1, pp. 83-96.

Pham-Thai, N.T., McMurray, A.J., Muenjohn, N. \& Muchiri, M. 2018, "Job engagement in higher education", Personnel Review, . 
Prahalad, C.K. \& Ramaswamy, V. 2004, "Co-creation experiences: The next practice in value creation", Journal of interactive marketing, vol. 18, no. 3, pp. 5-14.

Ramaswamy, V. 2009, "Leading the transformation to co-creation of value", Strategy \& Leadership,

Ramaswamy, V. 2008, "Co-creating value through customers' experiences: the Nike case", Strategy \& leadership, .

Randhawa, K., Wilden, R. \& Hohberger, J. 2016, "A bibliometric review of open innovation: Setting a research agenda", Journal of Product Innovation Management, vol. 33, no. 6, pp. 750-772.

Rich, B.L., Lepine, J.A. \& Crawford, E.R. 2010, "Job engagement: Antecedents and effects on job performance", Academy of management journal, vol. 53, no. 3, pp. 617-635.

Robinson, D., Perryman, S. \& Hayday, S. 2004, "The drivers of employee engagement", ReportInstitute for Employment Studies, .

Rogers, C.R. 1962, "The interpersonal relationship", Harvard educational review, vol. 32, no. 4, pp. 416-429.

Roll, L.C., Siu, O., Li, S.Y. \& De Witte, H. 2015, "Job insecurity: cross-cultural comparison between Germany and China", Journal of Organizational Effectiveness: People and Performance, .

Rooney, D. 2005, "Knowledge, economy, technology and society: The politics of discourse", Telematics and Informatics, vol. 22, no. 4, pp. 405-422.

Saks, A.M. 2006, "Antecedents and consequences of employee engagement", Journal of Managerial Psychology, .

Salanova, M., Agut, S. \& Peiró, J.M. 2005, "Linking organizational resources and work engagement to employee performance and customer loyalty: the mediation of service climate.", Journal of applied Psychology, vol. 90, no. 6, pp. 1217.

Salter, A., Criscuolo, P. \& Ter Wal, A.L. 2014, "Coping with open innovation: responding to the challenges of external engagement in R\&D", California management review, vol. 56, no. 2, pp. 77-94.

Sawhney, M., Verona, G. \& Prandelli, E. 2005, "Collaborating to create: The Internet as a platform for customer engagement in product innovation", Journal of interactive marketing, vol. 19, no. 4, pp. 4-17.

Schaufeli, W.B. \& Bakker, A.B. 2004, "Job demands, job resources, and their relationship with

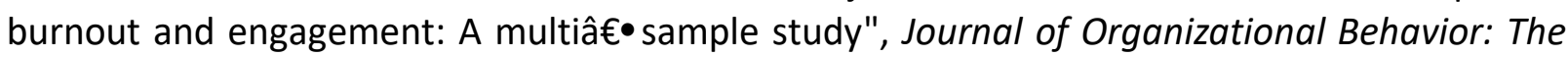
International Journal of Industrial, Occupational and Organizational Psychology and Behavior, vol. 25, no. 3, pp. 293-315.

Schaufeli, W.B., Salanova, M., González-Romá, V. \& Bakker, A.B. 2002, "The measurement of engagement and burnout: A two sample confirmatory factor analytic approach", Journal of Happiness studies, vol. 3, no. 1, pp. 71-92.

Scott, S.G. \& Bruce, R.A. 1994, "Determinants of innovative behavior: A path model of individual innovation in the workplace", Academy of management journal, vol. 37, no. 3, pp. 580-607.

Seibert, S.E., Silver, S.R. \& Randolph, W.A. 2004, "Taking empowerment to the next level: A multiplelevel model of empowerment, performance, and satisfaction", Academy of management Journal, vol. 47, no. 3, pp. 332-349.

Shalley, C.E., Zhou, J. \& Oldham, G.R. 2004, "The effects of personal and contextual characteristics on creativity: Where should we go from here?", Journal of management, vol. 30, no. 6, pp. 933958.

Shane, S.A. \& Ulrich, K.T. 2004, "Technological Innovation, Product Development, and Entrepreneurship in Management Science", Management Science, vol. 50, no. 2, pp. 133-144.

Shuck, B. \& Wollard, K. 2010, "Employee engagement and HRD: A seminal review of the foundations", Human resource development review, vol. 9, no. 1, pp. 89-110. 
Slater, S. F., Mohr, J. J., \& Sengupta, S. 2014, "Radical product innovation capability: Literature review, synthesis, and illustrative research propositions", Journal of Product Innovation Management, vol. 31, n. 3, pp. 552-566.

Slåtten, T. \& Mehmetoglu, M. 2011, "Antecedents and effects of engaged frontline employees", Managing Service Quality: An International Journal, .

Small, H. 1973, "Co-citation in the scientific literature: A new measure of the relationship between two documents", Journal of the American Society for information Science, vol. 24, no. 4, pp. 265-269.

Smedley, J. 2017, Information innovation: it's all about people. Information and Learning Science.

Smith, C.E. 1994, "The Merlin factor: leadership and strategic intent", Business Strategy Review, vol. 5 , no. 1 , pp. 67-84.

Sobel, M.E. 1982, "Asymptotic confidence intervals for indirect effects in structural equation models", Sociological methodology, vol. 13, pp. 290-312.

Suominen, A., Seppänen, M. and Dedehayir, O., 2019. A bibliometric review on innovation systems and ecosystems: a research agenda. European Journal of Innovation Management.

Teerikangas, S. \& Välikangas, L. 2013, "Engaged employees! An actor perspective on innovation" in Handbook of organizational and managerial innovation Edward Elgar Publishing, .

Trabucchi, D., \& Buganza, T. 2019, "Data-driven innovation: switching the perspective on Big Data". European Journal of Innovation Management.

Tranfield, D., Denyer, D. \& Smart, P. 2003, "Towards a methodology for developing evidenceinformed management knowledge by means of systematic review", British Journal of Management, vol. 14, no. 3, pp. 207-222.

Tuzovic, S., Wirtz, J. \& Heracleous, L. 2018, "How do innovators stay innovative? A longitudinal case analysis", Journal of Services Marketing, vol. 32, no. 1, pp. 34-45.

Van Eck, N.J. \& Waltman, L. 2014, "Visualizing bibliometric networks" in Measuring scholarly impact Springer, , pp. 285-320.

Van Looy, B., Ranga, M., Callaert, J., Debackere, K. \& Zimmermann, E. 2004, "Combining entrepreneurial and scientific performance in academia: towards a compounded and reciprocal Matthew-effect?", Research Policy, vol. 33, no. 3, pp. 425-441.

Vargo, S.L. \& Lusch, R.F. 2014, "Evolving to a new dominant logic for marketing" in The ServiceDominant Logic of Marketing Routledge, , pp. 21-46.

Verganti, R. \& Norman, D. 2019, "Why criticism is good for creativity", Harvard business review, .

Verganti, R. 2017, Overcrowded: designing meaningful products in a world awash with ideas, MIT Press.

Verona, G. \& Prandelli, E. 2002, "A dynamic model of customer loyalty to sustain competitive advantage on the web", European Management Journal, vol. 20, no. 3, pp. 299-309.

Von Hippel, E. 2005, "Democratizing innovation: The evolving phenomenon of user innovation", Journal für Betriebswirtschaft, vol. 55, no. 1, pp. 63-78.

Von Hippel, E. 1986, "Lead users: a source of novel product concepts", Management science, vol. 32 , no. 7, pp. 791-805.

Waltman, L., Van Eck, N.J. \& Noyons, E.C. 2010, "A unified approach to mapping and clustering of bibliometric networks", Journal of Informetrics, vol. 4, no. 4, pp. 629-635.

Welch, M. 2011, "The evolution of the employee engagement concept: communication implications", Corporate Communications: An International Journal, .

West, M.A. \& Farr, J.L. 1990, Innovation and Creativity at Work: Psycological and Organizational Strategies, John Wiley.

White, H.D. \& Griffith, B.C. 1981, "Author cocitation: A literature measure of intellectual structure", Journal of the American Society for information Science, vol. 32, no. 3, pp. 163-171. 
Zhexembayeva, N. (2020) Stop Calling It "Innovation". Harvard Business Review, February 19,2020 